\title{
Sustainability Thinking In The Paradigm Of Electrical/Electronic Engineering: Concept And Relevance
}

\author{
Nasiru Mukhtar, Muhammad Sukri Bn Saud
}

\begin{abstract}
Sustainability thinking plays a vital role for achieving a shift in environmental, economic, social and technical sustainability. Education has also been identified as an essential tool for achieving a sustainable future and improving the capacity of people to address sustainability issues which are inextricably tied to sustainable development. However, engineering curricula in Nigerian polytechnics is found to be deficient in terms of skills, knowledge and values in sustainability and its associated contexts/derivatives. This study therefore, investigated the perceptions of electrical/electronic engineering experts from academia and industry on the concept of sustainability and relevance of sustainability thinking in engineering education in Nigerian polytechnics. A qualitative approach was used in data collection through interview with experts in electrical/electronic engineering from both academia and industry. Findings showed that the participants clearly demonstrated an adequate understanding of the concept of sustainability thinking in line with the various United Nation's report on sustainable development. They have also shown divergent views on the notion of sustainability thinking, and have advanced strong reasons for why integrating sustainability thinking in engineering curricula is inevitable. Responses are generally in line with the global reasons for re-orienting engineering curricula. But planet's catastrophe are evidently on the increase in the Nigerian society, which suggests the need for incorporating sustainability thinking in engineering programmes as a new paradigm for sustainable development, to help curb out the menaces.
\end{abstract}

Index Terms: Concept of Sustainability, Meaning of Sustainability Thinking, Relevance of Sustainability Thinking

\section{INTRODUCTION}

Sustainability thinking plays a vital role for achieving a shift in environmental, economic, social and technical sustainability through learning about and understanding of the concept of sustainability, as well as of the link between the multiple crises to unsustainable environmental, economic, social and technical activities (UNESCO, 2011). Sustainability thinking also entails a re-orientation of values and attitudes and has to encompass a broad variety of actors, ranging from the individual consumer, to policy makers and multinational corporations (UNESCO, 2008). In order to prompt and facilitate sustainability thinking processes, neither financial incentives, nor regulations, or the pure transmission of knowledge about sustainability will be

Revised Manuscript Received on April 19, 2019.

Nasiru Mukhtar, Department of Science and Technology Education, Bayero University, Kano, Kano, Nigeria.

Muhammad Sukri Bn Saud, Department of Technical and Engineering Education, Universiti Teknologi Malaysia, Johor Bahru, Malaysia. sufficient (Doppelt, 2012). Therefore, the concept of Education for Sustainability/Sustainable Development (EfS/ESD) is a unique and valuable approach to making people think sustainably. This is because it is designed to facilitate the development of values and initiate the reconsideration of existing values and attitudes.

To ensure engineering education students possess a solid foundation in sustainability thinking, there must be a successful application and incorporation of sustainability principles and ideas in the engineering curricula. This integration will ensure that engineers acquire the knowledge and skills to provide inventive solutions to complicated challenges in the face of uncertainty and frequently contradictory goals (Huntzinger, Hutchinson, Gierke and Sutherland, 2007). However, the principles and ideas of sustainability cannot be realistically integrated in to engineering education curricula in the hopes of making the engineering students think sustainably, devoid of sufficiently tackling the issues in intellectual development. Therefore, the issue of sustainability thinking cannot be adequately understood devoid of discussion in intellectual development, since both have a symbiotic relationship. More so, promoting sustainability thinking in engineering education is equivalent to promoting engineering students' intellectual development and creative thinking. As such, comprehending the diverse intellectual development stages and the methods to promote progressions between them are a precondition for assisting students arrive at the sustainability thinking to function efficiently as engineering professional in the 21st century (Felder and Brent, 2004).

Furthermore, interconnecting social, economic, political and environmental issues is a critical feature of sustainable development. Establishing such nexus requires a deeper, more determined way of thinking about education, one that holds on to a devotion to significant analysis while nurturing creativity and innovation. In a nutshell, it requires that education encourages a system of ideals, ethics and values that is responsive to cultural identity, multicultural discourse, democratic decision-making and the suitable application and management of natural resources. The potential of education is enormous. Education as a social learning for sustainability, can increase concern over unsustainable practices and increase our capacity to confront 
and master change. Education not only informs people, it also changes them. Education as a means for personal enlightenment and for cultural renewal is not only central to sustainable development; it is humanity's best hope and most effective means in the quest to achieve sustainable development (UNESCO, 2002). Ideally, education for sustainability thinking is the approach that not only provides theoretical information to people about sustainability but also gives them practical tools which are used to move society towards sustainability (Gu, Gomes and Brizuela, 2011). Furthermore, UNESCO, (2010) affirmed that education for sustainability thinking not only provides scientific and technical skills, it also provides the motivation, justification, and social support for pursuing and applying them. As such stakeholders in engineering curricula in developing countries must be intensely alarmed that much of engineering programs plunge far short of what is expected. Improving the quality and coverage of engineering programs and recreating its goals to realize the relevance of sustainable development must be among higher education institutions' highest precedence.

Sustainability thinking is a process of learning how to arrive at decisions that recognizes the longstanding prospect of the economy, ecology and social well-being of all communities. In essence therefore, developing the capacity for future-oriented thinking is a crucial job of education. This development signifies a novel mission of education, a mission that assists learners best realized the world in which they live, tackling the complication and interrelatedness of challenges for instance, poverty, wasteful consumption, environmental degradation, urban decay, population growth, gender inequality, health, conflict and the violation of human rights that threaten our future. In addition, the vision of sustainability thinking emphasizes an integrated multidisciplinary approach thereby creating the knowledge and skills required for a sustainable future as well as changes in values, behavior, and lifestyles. This necessitates us to reorient education systems, policies and practices towards sustainability thinking in order to allow everyone, young and old, to make decisions and act in culturally proper and locally pertinent means to remedy the obstacles that scare our common future. To this end, using this approach, people of different ages can become empowered to build and assess alternative visions of a sustainable future and to accomplish these visions through working creatively with others.

In essence therefore, in order to adequately realize the goals of sustainability as emphasized above, especially in technical institutions in the developing countries, it is crucial to understand the concept of sustainability, and relevance of integrating sustainability thinking in electrical/electronic engineering curriculum in polytechnics.

\section{OBJECTIVE}

This paper reported on the findings of a qualitative study in which electrical/electronic engineering experts from academia and industry were interviewed about their perceptions/views on the concept of sustainability and relevance of sustainability thinking in engineering education in Nigerian polytechnics.

\section{METHODOLOGY}

The study adopted a qualitative approach in data collection through semi-structured interview with the purposely selected research participants. This research was accomplished at the polytechnics and manufacturing industries of Nigeria with total population of 274 experts. Cluster sampling was used to select four states out of seven in the study area, while Quota sampling procedure was used in selecting 10 participants, which includes 6 electrical/electronic lecturers from the six polytechnics, (i.e., one from each institution); and 4 electrical/electronic engineering personnel from manufacturing industries (i.e., one from each sampled state). The interview guide/protocol used in this study was validated by 6 electrical/electronic experts who are practitioners in the areas of sustainable development, education for sustainable development, and engineering education for sustainable development.

\section{METHOD OF DATA ANALYSIS}

The data for analyzing and answering the research questions was collected using interview with the participants. The researchers in the first place, visited the institutions and manufacturing industries slated for this study to introduce the purpose of the study and make appointments for the interview with the selected participants. Later the interviews were conducted one after the other on the scheduled dates, venues and times.

Moreover, the data analysis was started by transcribing the audio-recorded version of the data immediately after the first interview was carried out. The researchers continued in the same manner of conducting and transcribing the interview, before conducting the next interview until the researcher felt the data reached a saturation point. The analysis continued with thorough reading and re-reading the transcribed data which was later presented to the interview participants for their corrections and confirmations. This was then exported in to Nvivo version 11 to help organize the data. Thematic data analysis was accomplished using Nvivo version 11 to condense the data to manageable and meaningful codes based on the research questions. The outcomes of the analysis were modified in to a framework Furthermore, broad analysis on the perceptions of the interview participants on their understanding of the concept of sustainability and sustainability thinking, relevance of sustainability thinking in electrical/electronic engineering are presented in the successive sections. 


\section{FINDINGS}

Table I: Findings on the Concept of Sustainability.

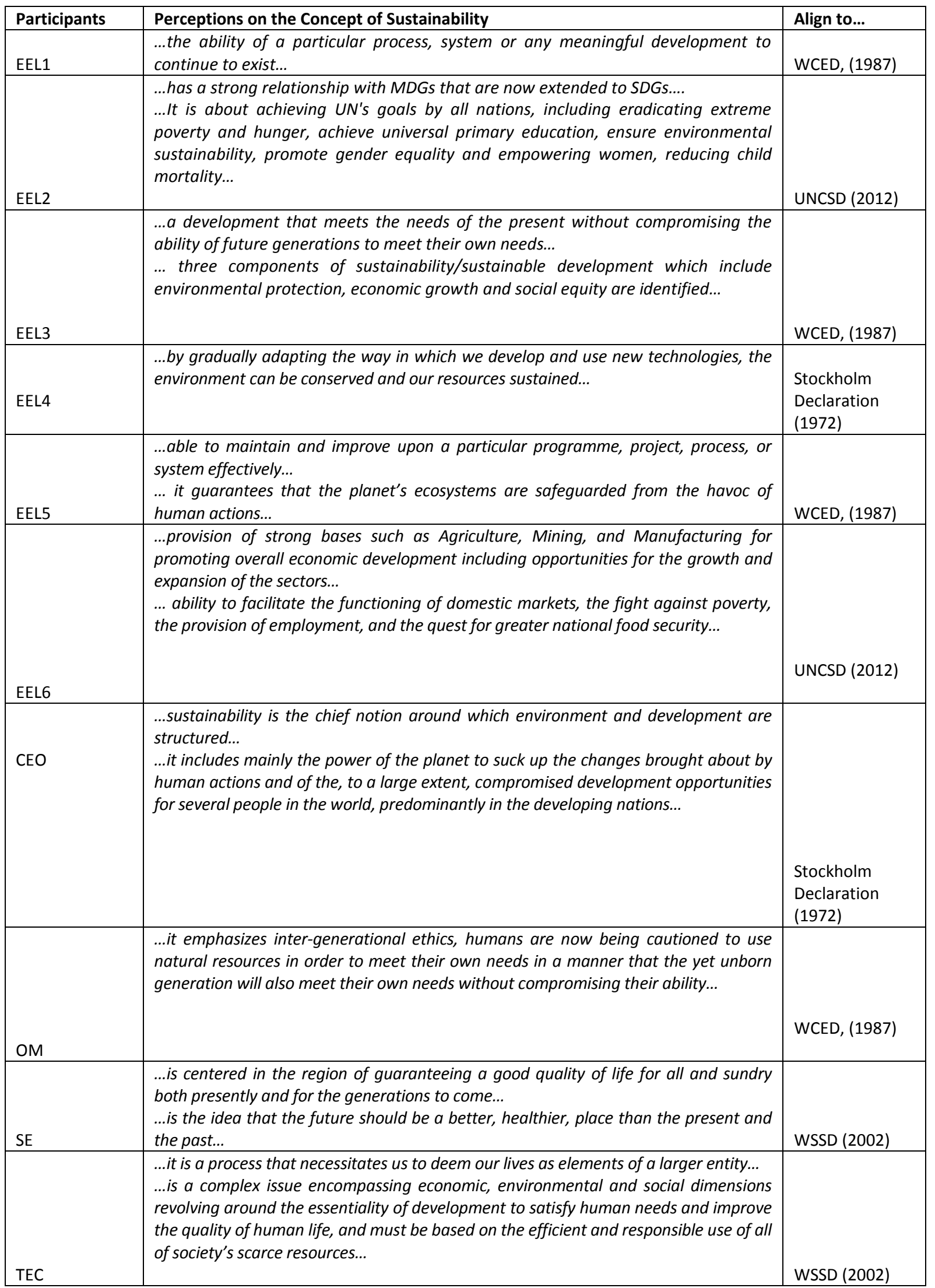


International Conference on Recents Advancements in Engineering and Technology (ICRAET-18) |15th and 16th March 2019|Siddhartha Institute of Technology \& Sciences, Telangana, India.

Table 1 revealed how the participants perceived the concept of sustainability in which they have demonstrated an adequate understanding on the concept of sustainability in line with the various UN's report on sustainable development. The researchers tried to align each perception of the participant with a particular report of the UN on sustainable development.

Table II: Findings on the Concept of Sustainability Thinking

\begin{tabular}{|c|c|c|c|c|}
\hline \multirow[b]{2}{*}{ Participants } & \multicolumn{4}{|c|}{ Themes } \\
\hline & $\begin{array}{l}\text { Acquiring Sustainability } \\
\text { Competencies }\end{array}$ & $\begin{array}{c}\text { Embed } \\
\text { Sustainability in } \\
\text { Curricula }\end{array}$ & $\begin{array}{l}\text { Sustainability } \\
\text { Consciousness }\end{array}$ & $\begin{array}{l}\text { Comprehensive and } \\
\text { Critical Thinking }\end{array}$ \\
\hline EEL1 & $\begin{array}{l}\text {...acquiring knowledge of } \\
\text { sustainability... }\end{array}$ & & $\begin{array}{l}\text {...guides whatever action } \\
\text { or decision one has to } \\
\text { take... }\end{array}$ & $\begin{array}{l}\text {...acquiring critical } \\
\text { thinking skills... }\end{array}$ \\
\hline EEL2 & $\begin{array}{l}\text {...use of natural resources } \\
\text { in a way that does not } \\
\text { lead to diminished quality } \\
\text { of life socially, } \\
\text { economically and } \\
\text { environmentally... }\end{array}$ & $\begin{array}{l}\text {...a result of } \\
\text { adequately } \\
\text { embedding } \\
\text { sustainability in to } \\
\text { our academic } \\
\text { programmes... }\end{array}$ & $\begin{array}{l}\text {...is the ability of the } \\
\text { graduates to be able to } \\
\text { think sustainably in their } \\
\text { various places of work, } \\
\text { and in the broader } \\
\text { society }\end{array}$ & $\begin{array}{l}\text {...acquiring skills in } \\
\text { systemic and } \\
\text { comprehensive thinking } \\
\text { will lead to sustainability } \\
\text { thinking... }\end{array}$ \\
\hline EEL3 & ...sustainability literacy... & & & $\begin{array}{l}\text {...skills in critical } \\
\text { thinking and problem } \\
\text { solving is the pathway to } \\
\text { sustainability thinking... }\end{array}$ \\
\hline EEL4 & & $\begin{array}{l}\text {...ability to always } \\
\text { bring forth the } \\
\text { issues of } \\
\text { maintainability } \\
\text { which leads to } \\
\text { sustainability of the } \\
\text { programme, project, } \\
\text { process, or system... }\end{array}$ & & \\
\hline EEL5 & $\begin{array}{l}\text {...it can be equated with } \\
\text { "sustainability education" } \\
\text { or "sustainability } \\
\text { awareness... }\end{array}$ & & & \\
\hline EEL6 & & & $\begin{array}{l}\text {...taking very serious } \\
\text { consideration of society } \\
\text { and the wider } \\
\text { environment in decision } \\
\text { making choices... }\end{array}$ & \\
\hline $\mathrm{OM}$ & & $\begin{array}{l}\text {...is a way of } \\
\text { thinking about how } \\
\text { we organize our } \\
\text { lives and work } \\
\text { including education } \\
\text { system, so that we } \\
\text { don't destroy our } \\
\text { resources, }\end{array}$ & & $\begin{array}{l}\text {... thinking around the } \\
\text { complex interactions } \\
\text { among the environmental, } \\
\text { social, economic and } \\
\text { cultural systems... }\end{array}$ \\
\hline
\end{tabular}




\begin{tabular}{|c|c|c|c|}
\hline CEO & & $\begin{array}{l}\text {...always thinking of the } \\
\text { consequences of one's } \\
\text { actions to the immediate } \\
\text { and wider environment } \\
\text { and how such would } \\
\text { negatively affect the life of } \\
\text { the generations yet } \\
\text { unborn... }\end{array}$ & $\begin{array}{l}\text {... implies thinking in a } \\
\text { comprehensive and } \\
\text { systemic manner, as } \\
\text { against differentiative } \\
\text { thinking, taking all } \\
\text { aspects of life in to } \\
\text { consideration... }\end{array}$ \\
\hline SE & & & $\begin{array}{l}\text {...in sustainability } \\
\text { thinking, it is not enough } \\
\text { to be able to analyze and } \\
\text { synthesize a system, but } \\
\text { also to be able to predict } \\
\text { the relationship among } \\
\text { the components that form } \\
\text { the system, as well as the } \\
\text { relationship between the } \\
\text { individual components } \\
\text { and the system as a } \\
\text { whole... }\end{array}$ \\
\hline TEC & $\begin{array}{l}\text {...is a capability to take on } \\
\text { efficiently with social, } \\
\text { environmental and } \\
\text { economic transformation } \\
\text { and challenges in the } \\
\text { modern-day world... }\end{array}$ & $\begin{array}{l}\text {...takes into consideration } \\
\text { our commitments to future } \\
\text { generations and how the } \\
\text { decisions one takes } \\
\text { impact on the betterment } \\
\text { of the public and wellness } \\
\text { of the generations to } \\
\text { come... }\end{array}$ & \\
\hline
\end{tabular}

Table 2 shows the concept of sustainability thinking as perceived by the experts, and this undoubtedly clears the ground for the researchers to have divergent views on the notion of sustainability thinking. Ultimately, the research participants' perceptions suggested for the incorporation of sustainability competencies in the academic curricula for a graduate to think sustainably. Their answers were analyzed and presented under 4 themes which include: Acquiring Sustainability Competencies, Embed Sustainability in the Curricula, Sustainability Consciousness, and Comprehensive/Critical Thinking. 
International Conference on Recents Advancements in Engineering and Technology (ICRAET-18) |15th and 16th March 2019|Siddhartha Institute of Technology \& Sciences, Telangana, India.

Table III: Findings on the Relevance of Sustainability Thinking in Electrical/Electronic Engineering Curriculum in Nigerian Polytechnics

\begin{tabular}{|c|c|c|c|c|}
\hline Participant & $\begin{array}{l}\text { Global Institutional } \\
\text { Influence }\end{array}$ & Sustainable Activities & $\begin{array}{c}\text { National and } \\
\text { International } \\
\text { Outcry }\end{array}$ & $\begin{array}{c}\text { Sustainable } \\
\text { Manufacturing } \\
\text { Production }\end{array}$ \\
\hline EEL1 & $\begin{array}{l}\text {...because } \\
\text { sustainability has been } \\
\text { registered in the } \\
\text { curriculum and other } \\
\text { aspects of many } \\
\text { institutions in the } \\
\text { world... }\end{array}$ & & & \\
\hline EEL2 & $\begin{array}{l}\text {...some institutions in } \\
\text { developed and } \\
\text { developing countries } \\
\text { have adequately } \\
\text { integrated } \\
\text { sustainability education } \\
\text { in their engineering } \\
\text { programmes... }\end{array}$ & $\begin{array}{l}\text {...to me it will not only } \\
\text { be a vital component, } \\
\text { but rather an } \\
\text { inevitable component } \\
\text { of the curriculum } \\
\text { unless we are not } \\
\text { going to be } \\
\text { sustainable in our } \\
\text { everyday actions... }\end{array}$ & & $\begin{array}{l}\text {...graduates are the } \\
\text { very people that will } \\
\text { man our industries } \\
\text { and other government } \\
\text { organizations; as such } \\
\text { they have to be trained } \\
\text { on how to become } \\
\text { sustainable in their } \\
\text { dealings and how to } \\
\text { promote sustainability } \\
\text { in their } \\
\text { organizations... }\end{array}$ \\
\hline EEL3 & & $\begin{array}{l}\text {...because } \\
\text { electrical/electronic } \\
\text { engineering } \\
\text { programmes in } \\
\text { Nigeria will be } \\
\text { graduating students } \\
\text { that will take up the } \\
\text { challenges of } \\
\text { sustainability } \\
\text { anywhere they found } \\
\text { themselves... }\end{array}$ & & $\begin{array}{l}\text {...if the graduates are } \\
\text { not trained in } \\
\text { sustainability, then the } \\
\text { unsustainable } \\
\text { activities of the } \\
\text { manufacturing } \\
\text { industries will never } \\
\text { be put to a stop }\end{array}$ \\
\hline EEL4 & $\begin{array}{l}\text {.. it would be a } \\
\text { significant element of } \\
\text { our engineering } \\
\text { curricula in the } \\
\text { polytechnics... }\end{array}$ & & $\begin{array}{l}\text {...sure, because } \\
\text { polytechnics are } \\
\text { meant to train for } \\
\text { industries, and } \\
\text { industries are now } \\
\text { under excessive } \\
\text { pressure nationally } \\
\text { and internationally to } \\
\text { be sustainable in their } \\
\text { operations... }\end{array}$ & \\
\hline EEL5 & & & & $\begin{array}{l}\text {...the students will } \\
\text { acquire knowledge and } \\
\text { abilities in } \\
\text { sustainability to be } \\
\text { able to contribute in } \\
\text { eliminating problems } \\
\text { such as uncontrolled } \\
\text { solid and liquid wastes } \\
\text { disposal, pollution and } \\
\text { released of waste water } \\
\text { from industries etc... }\end{array}$ \\
\hline
\end{tabular}

Published By: 


\begin{tabular}{|c|c|c|c|c|}
\hline EEL6 & $\begin{array}{l}\text {...Yes. Because, globally } \\
\text { the issues of embedding } \\
\text { sustainability, not only } \\
\text { in the curricula, but also } \\
\text { in the diverse activities } \\
\text { of higher institutions are } \\
\text { not a new incident... }\end{array}$ & & & \\
\hline CEO & & $\begin{array}{l}\text {... Fair enough. } \\
\text { Because if this } \\
\text { happens, then } \\
\text { electrical/electronic } \\
\text { engineering } \\
\text { programmes in our } \\
\text { Polytechnics will now } \\
\text { be turning out } \\
\text { graduates ready to face } \\
\text { most of the } \\
\text { sustainability } \\
\text { challenges }\end{array}$ & $\begin{array}{l}\text {... higher education } \\
\text { institutions were } \\
\text { charged with the } \\
\text { responsibility of } \\
\text { training, educating } \\
\text { and awareness for } \\
\text { sustainable } \\
\text { development... }\end{array}$ & \\
\hline $\mathrm{OM}$ & & $\begin{array}{l}\text {...sure. Because } \\
\text { generally education, in } \\
\text { addition to being a } \\
\text { human right, is a pre- } \\
\text { requisite for achieving } \\
\text { sustainability... }\end{array}$ & & $\begin{array}{l}\text {... can serve as an } \\
\text { instrument for } \\
\text { achieving sustainable } \\
\text { development, as well as } \\
\text { empower individuals, } \\
\text { groups, communities, } \\
\text { and organizations to } \\
\text { take actions towards } \\
\text { sustainable } \\
\text { development... }\end{array}$ \\
\hline SE & & $\begin{array}{l}\text {....Why not? Because } \\
\text { referring to Agenda } 21 \\
\text { it stated that } \\
\text { "education is critical } \\
\text { for promoting } \\
\text { sustainable } \\
\text { development and } \\
\text { improving the capacity } \\
\text { of all people to address } \\
\text { environment and } \\
\text { development issues... }\end{array}$ & & $\begin{array}{l}\text {... It is a necessary tool } \\
\text { for good governance, } \\
\text { informed decision } \\
\text { making and the } \\
\text { promotion of } \\
\text { democracy... }\end{array}$ \\
\hline TEC & & $\begin{array}{l}\text {... Yes, of course yes, } \\
\text { because the trained } \\
\text { technologists have an } \\
\text { important role in } \\
\text { society and nature, } \\
\text { bearing in mind that } \\
\text { their activities have a } \\
\text { direct impact on } \\
\text { people's lives and } \\
\text { environment }\end{array}$ & & \\
\hline
\end{tabular}

Table 3 shows the answers the research participants presented when asked about why they think sustainability thinking is relevant to be integrated in to electrical/electronic engineering curriculum in Nigerian polytechnics. Their responses are generally in line with the reasons for re-orienting engineering curricula. The themes generated from their responses include Global Institutional Influence, Sustainable Engineering/Manufacturing Activities, and National and International Outcry for sustainable curricula. 


\section{DISCUSSION}

\section{A. Discussion of the findings on the concept of sustainability}

The findings of this research on the perceptions of the participants on the concept of sustainability bring to light, by and large, that their perceptions of the concept is explicitly the same with definitions, meanings, descriptions and conceptualizations of the term as presented in various UN documents. For instance, one of the participants described sustainability as: meaningful development to continue to exist...

Another participant stressed that the concept of sustainability

...is a process that necessitates us to deem our lives as elements of a larger entity... ...is the idea that the future should be a better, healthier, place than the present and the past...

Yet another participant claimed that the concept of sustainability

...is centered in the region of guaranteeing a good quality of life for all and sundry both presently and for the generations to come...

These perceptions and many more from other participants were aligned to UN reports, conferences, charters and declarations. These include Stockholm Declarations (1972), WCED (1987), popularly known as Brundtland Report, WSSD (2002) and UNCSD (2012).

The popular definition of SD as provided by Brundtland Report is 'development that meets the needs of the present without compromising the ability of future generations to meet their own needs' (WCED, 1987, p.43). Sustainability has also been viewed as a field of study of how natural system function, remain diverse and produce everything it needs for the ecology to remain in balance. It also acknowledges that human civilization takes resources to sustain our modern way of life (Teixeira and Krings, 2015). Calder and Dautremont-Smith (2009), reported that sustainability is a growing imperative in higher education in America, and stressed that scholars define it both narrowly as a the long-term protection and health of natural environment, and broadly as the triple bottom line of environmental health, economic viability and social wellbeing. Sustainability is a notion, a practice and an allembracing goal that preferably permits to deal with existing circumstances of intertwined environmental, economic and social crises considered collectively as 'global change' (Huge, Maclean and Vargas, 2017). (2007) estimated that there are around 300 definitions of sustainability emerging from different disciplines and field of specializations, while Besong and Holland (2015) maintained that the concept of sustainability remains controversial with no universally acceptable definition, but is generally conceived as the ability to maintain something for a long time at a specific rate or level. Acero and Savaget (2014) are of the view that, instead of setting common goals, sustainability opens up the scope for multiple expectations about what should be developed and what is to be sustained, for how long, and for the benefit of whom. ...the ability of a particular process, system or any

Ultimately, Johnston, Everard, Santillo, and Robert

B. Discussion of the findings on the concept of sustainability thinking

The results of this qualitative study particularly on the concept of sustainability thinking based on the perceptions of the participants showed a significant degree of similarity with the general or global meaning of the concept of sustainability consciousness and awareness (Kalsoom and Khanam, 2017, Olsson and Gericke, 2016, de Carvalho, de Fátima Salgueiro, and Rita, 2015). One participant sees sustainability thinking as:

...use of natural resources in a way that does not lead to diminished quality of life socially, economically and environmentally...

For another participant, sustainability thinking:

... implies thinking in a comprehensive and systemic manner, as against differentiative thinking, taking all aspects of life in to consideration...

While another participant viewed sustainability thinking as:

... thinking around the complex interactions among the environmental, social, economic and cultural systems... ...is a way of thinking about how we organize our lives and work including education system, so that we don't destroy our most precious resources, the planet

The research participants accounted for several specific meanings of sustainability thinking and were captured and categorized under Acquiring Sustainability Competencies (ASC), Embed Sustainability in Curriculum (ESC), Acquiring Competencies in Critical Thinking (ACCT), Sustainability Consciousness (SC), and Comprehensive Thinking (CT).

Sustainability thinking in engineering programmes relates to a design of human and industrial systems to ensure that humankind's use of natural resources and cycles does not lead to diminished quality of life due to either losses in further economic opportunities or to adverse impacts on social conditions, human health and the environment (Mihelcic, et al., 2003 in Huntzinger, et al., 2007). Kuhlman and Farrington (2010) described sustainability thinking as the process of maintaining wellbeing over a long, perhaps even an indefinite period. It supposes to guide the world inhabitants in preparing what resources we bequeath to coming generations through the sustainable use (production and consumption) of natural resources. Mulder (2006) as cited in Gagnon, Leduc and Savard (2012) opined that sustainability is not an add-on criterion. It is about all characteristics and attributes that an engineer should meet Sustainability issues must thus be considered by engineers in all their activities from project initiation to the production/construction stage bearing in mind recycling of components and materials.

Therefore, the need to prepare engineering students with the knowledge, skills and abilities to customize engineering and technological solutions to the local, social, economic, political, cultural and environmental contexts of sustainability thinking cannot be overemphasized. 
C. Discussion of the findings on the relevance of sustainability thinking

Findings of this qualitative study on the relevance of sustainability thinking in engineering education in Nigeria generally reveals that sustainability thinking is extremely required to be integrated in to the engineering programmes in Nigeria. For example, one participant stated that:

...to me it will not only be a vital component, but rather an inevitable component of the curriculum unless we are not going to be sustainable in our everyday actions...

Some other participant lamented that

... if the graduates are not trained in sustainability, then the unsustainable activities of the manufacturing industries will never be put to a stop...

Another participant added that sustainability thinking

...contributes in bearing the responsibilities of imparting knowledge, awareness, technologies and tools for creating sustainable future through educating most of the people who develop and manage society's institutions...

Various reasons were advanced by the research participants whom the researcher coded under Global Institutional Influence (GII), Sustainable Activities (SA), National and International Outcry (NIO), and Sustainable Manufacturing Productions (SMP).

These findings are more or less in line with the objectives of the United Nation Commission for Sustainable Development in its various reports and outcome of conferences. The findings also naturally align themselves with several research findings carried out globally by scholars in sustainability. Educating engineers and technologists in sustainability thinking can help form new generations who care about global issues and engage in tackling social, economic and environmental challenges. The 2030 Agenda for Sustainable Development recognizes the critical role of education in reaching sustainability goals, calling on all countries "to ensure, by 2030 , that all learners acquire the knowledge and skills needed to promote sustainable development, including, among others, through education for sustainable development and sustainable lifestyles, human rights, gender equality, promotion of a culture of peace and nonviolence, global citizenship and appreciation of cultural diversity and of culture's contribution to sustainable development" (Target 4.7, Education 2030, Incheon Declaration and Framework for Action, page 20). Calder and Dautremont-Smith (2009) maintained that fostering a more sustainable world is arguably the most logical outcome of the higher education endeavor.

Steiner and Laws (2006) warned that the demands of industry and employers in many sectors are shifting from graduates that are disciplinary specialists capable of solving routine technical problems to graduates armed with competencies in sustainability thinking necessary for tackling complex real-world problems. Sustainability thinking is not only confined to local concerns such as conserving water, fuel consumption and the use of degradable material in our day-to-day living, but it is part of a set of universal priorities for all of us on this planet (Remington-Doucette, et al., 2013). Engineering education has the potential to play an important role in preparing students to contribute to deal with problems such as those referred by Lonngren and Svanstrom (2015) as Wicked Sustainability Problems.

Sustainability is a major and expanding issue for higher education and many institutions are attempting, in different ways, to embed programmes based on the principles and practices of sustainability within their operations (Ukpai, 2012). Wiek, Withycombe, Redman and Mills (2011) stated that sustainability education programmes do not just educate students for 'green jobs' but train systematic problem solvers, change agents and transition managers. It is highly desirable that as many graduates as possible should be 'sustainability literate' when they leave TVE institutes, having had the chance whilst at the school to discover sustainability issues within their own lives, their chosen branch of learning and their future careers.

\section{CONCLUSION}

This paper attempted to empirically investigate the level of understanding of Nigerian electrical/electronic engineering personnel in both academia and industry on the concept of sustainability, and sustainability thinking and relevance of sustainability thinking in engineering programmes in Nigerian polytechnics. This is necessary in this material time because engineering programmes in polytechnics are set to ensure students are taught among others, the right thinking skills in the application/utilization of available local materials and technologies in solving immediate engineering and technological problems in the society. Albeit, the findings of the paper revealed positive and significant results as per the objectives of the study, yet clear evidences are available which showed that Nigerian society is increasingly promoting planet's catastrophe, such as decreased biodiversity, increased $\mathrm{CO} 2$ emission, pollution, depletion of natural resources etc. Therefore, the need to incorporate sustainability thinking as a new paradigm for sustainable development in our engineering programmes cannot be overemphasized.

\section{REFERENCES}

1. Acero, L., Savaget, P.,(2014). Plural understandings of sociotechnical progress within the OECD. In: 12th Globelics International Conference, 19-31 October 2014 (Addis Ababa, Ethiopia).

2. Besong, F., \& Holland, C. (2015). The dispositions, abilities and behaviours (DAB) framework for profiling learners' sustainability competencies in higher education.

3. Calder, W., \& Dautremont-Smith, J. (2009). Higher education: More and more laboratories for inventing a sustainable future. Agenda for a sustainable America, 93107.

4. de Carvalho, B. L., de Fátima Salgueiro, M., \& Rita, P. (2015). Consumer Sustainability Consciousness: A five dimensional construct. Ecological Indicators, 58, 402410.

5. Declaration, I. (2015). Framework for Action. Towards inclusive and equitable quality

6. Doppelt, B. (2012). The Power of Sustainable Thinking:" How to Create a Positive Future for the Climate, the Planet, Your Organization and Your Life": Routledge. 
7. Felder, R.M., \& Brent, R. (2004). The intellectual development of science and engineering students. Part 2: Teaching to promote growth, Journal of Engineering Education, 93(4), 269 - 277

8. Gagnon, B., Leduc, R., \& Savard, L. (2012). From a conventional to a sustainable engineering design process: different shades of sustainability. Journal of Engineering Design, 23(1), 49-74.

9. Gu, C.C., Gomes, T., \& Brizuela, V.S. (2011). Technical and vocational education and training in support of strategic sustainable development. Unpublished $\mathrm{M}$. ENGR. Thesis, School of Engineering, Blekinge Institute of Technology, Karlskrona, Sweden

10. Hugé, J., Mac-Lean, C., \& Vargas, L. (2017). Maturation of sustainability in engineering faculties-From emerging issue to strategy? Journal of Cleaner Production.

11. Huntzinger, D. N., Hutchins, M. J., Gierke, J. S., \& Sutherland, J. W. (2007). Enabling sustainable thinking in undergraduate engineering education. International Journal of Engineering Education, 23(2), 218.

12. Johnston, P., Everard, M., Santillo, D., Robert, K., (2007). Reclaiming the definition of sustainability. Environ. Sci. Pollut. Res. 14, 60-66.

13. Kalsoom, Q., \& Khanam, A. (2017). Inquiry into sustainability issues by preservice teachers: A pedagogy to enhance sustainability consciousness. Journal of Cleaner Production, 164, 1301-1311.

14. Kuhlman, T., \& Farrington, J. (2010). What is sustainability? Sustainability, 2(11), 3436-3448.

15. Lonngren, J., \& Svanstrom, M. (2015). Assessing "Wicked sustainability problem"-literacy in engineering education. Paper presented at the American Society for Engineering Education. Annual Conference \& Exposition, Seattle, WA.

16. Olsson, D., \& Gericke, N. (2016). The adolescent dip in students' sustainability consciousness-Implications for education for sustainable development. The Journal of Environmental Education, 47(1), 35-51.

17. Remington-Doucette, S. M., Hiller Connell, K. Y., Armstrong, C. M., \& Musgrove, S. L. (2013). Assessing sustainability education in a transdisciplinary undergraduate course focused on real-world problem solving: a case for disciplinary grounding. International Journal of Sustainability in Higher Education, 14(4), 404-433.

18. Sohn, L. B. (1973). Stockholm Declaration on the Human Environment, The. Harv. Int'l. LJ, 14, 423.

19. Teixeira, S., \& Krings, A. (2015). Sustainable social work: An environmental justice framework for social work education. Social Work Education, 34(5), 513-527.

20. Ukpai, U.I. (2012). Effective Management of Nigerian Polytechnics: Challenges and Remedies. Paper Presented at the 3rd Annual National Conference of School of General Studies on the Theme: Trends in Nigerian Tertiary education at Abia State Polytechnic, Aba, November 13th - 16th, 2012

21. UNESCO (2008). Education for All by 2015, Will We Make It? EFA Global Monitoring Report, Oxford: Oxford University Press, Downloaded from efareport.unesco.org

22. UNESCO (2010). Guidelines for TVET Policy Review (Draft). UNESCO, Addis Ababa

23. UNESCO, (2002). Education for Sustainability . From Rio to Johannesburg: Lessons learnt from a Decade of Commitment. World Summit on Sustainable Development, (UNESCO). Johannesburg. Available at http://unesdoc.unesco.org/images/0012/001271/127100e. pdf

24. UNESCO. (2011). Financing education in sub-Sahara Africa: Meeting the challenges of expansion, equity and quality, UNESCO
25. WCED, (1987). Our Common Future. World Commission on Environmental and Development, Oxford University Press, Oxford

26. Wiek, A., Withycombe, L., Redman, C., \& Mills, S. B. (2011). Moving forward on competences in sustainability research and problem solving. Environment, 53(2), 3-13.

\section{AUTHORS PROFILE}

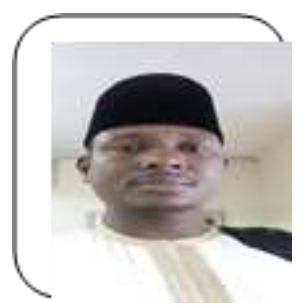

First Author Nasiru Mukhtar is presently a $\mathrm{PhD}$ candidate in the Department of Technical and Engineering Education, Faculty of Social Sciences and Humanities, Universiti Teknologi Malaysia. He has completed his Master and Bachelor Degrees in Electrical/Electronic Technology in Federal University of Technology, Minna, and Abubakar Tafawa Balewa University, Bauchi, both in Nigeria, respectively. He has published and co-authored articles in the fields of occupational skills and programme evaluation. His $\mathrm{PhD}$ research centers on Education for Sustainability (EfS). Nasiru works with Bayero University, Kano, Nigeria, and actively involved in Teaching and Research.

Second Author personal profile which contains their education details, their publications, research work, membership, achievements, with photo that will be maximum 200-400 words.

Third Author personal profile which contains their education details, their publications, research work, membership, achievements, with photo that will be maximum 200-400 words. 